\title{
Exotic plant disease threats to the New Zealand avocado industry and climatic suitability: a review
}

\author{
Kerry R. Everett ${ }^{1, \star}$ and Brad Siebert ${ }^{2}$ \\ ${ }^{1}$ The New Zealand Institute for Plant \& Food Research Limited, Private Bag 92169, Mt Albert, \\ Auckland 1142, New Zealand \\ ${ }^{2}$ New Zealand Avocado, PO Box 13267, Tauranga 3141, New Zealand \\ ${ }^{*}$ Corresponding author: Kerry.Everett@plantandfood.co.nz
}

\begin{abstract}
The avocado industry was established in New Zealand from several importations dating back to 1907. Several serious pathogens found elsewhere in the world were not imported. A literature review and internet search were conducted to determine what serious avocado pathogens are not present in New Zealand and the potential impact they could have if they established. Relevant information was summarised for six pathogens determined to be the most serious of avocado and not known to be present in New Zealand: avocado sunblotch viroid (ASBVd); Pseudocercospora purpurea (cercospora spot); Raffaelea lauricola (laurel wilt); Fusarium sp. (fusarium dieback); Phellinus noxius (brown root rot); and Sphaceloma perseae (avocado scab). Laurel wilt, brown root rot, cercospora spot and fusarium dieback could become established in New Zealand if the climate here becomes warmer but establishment of ASBVd and avocado scab (which are not restricted to hot climates) is more likely.
\end{abstract}

Keywords Sphaceloma perseae, Pseudocercospora purpurea, brown root rot, Euwallacea sp., Raffaelea lauricola, Xyleborus glabratus, redbay ambrosia beetle, Fusarium sp., Avocado sunblotch viroid.

\section{INTRODUCTION}

The avocado (Persea americana) is a subtropical Lauraceous tree that produces oil rich fruit. Avocados originate from middle America (Mexico, West Indies and Guatemala) and avocado plants were first imported into Tauranga, New Zealand as seedlings in 1907 (Green 1927). Several more plants were imported to Tauranga and Wanganui in 1917, followed by the importation of grafted avocados from California to Gisborne and Tauranga in 1940 (White 2001). More recent importations of new rootstocks and fruiting varieties from South Africa and California took place since 1999. The 'Hass' variety is the most commonly grown avocado in New Zealand and was probably imported with the batch of grafted avocados in 1940 (White 2001).
Avocados in New Zealand are affected by a number of plant pathogens, of which the most common are two root invaders (Phytophthora cinnamomi and Verticillium dahliae) and pathogens that cause rots in ripe fruit (Colletotrichum acutatum, Colletotrichum gloeosporioides, Botryosphaeria dothidea, Neofusicoccum parvum (syn. B. parva) and Phomopsis sp.). These pathogens have a wide host range and may have originated from infected host material already present in New Zealand or from infected avocado plant material imported in 1907, 1917 and 1940. Most fungi that infect fruit to cause rots will also asymptomatically infect vegetative tissue (Everett et al. 1999; Hartill \& Everett 2002; Everett et al. 2003). The first record of an avocado fruit rot was of C. gloeosporioides 
(Brien 1939), and the first record of a root disease was of Phytophthora cinnamomi (Zentmeyer 1965), then the vascular wilt pathogen $V$. dahliae (Fletcher 1976). The remaining commonly occurring fruit rot pathogens were first reported by Boesewinkel (1982) (C. acutatum), Hartill (1987) (N. parvum, Phomopsis sp.) and Hartill et al. (1991a,b) (B. dothidea).

Biosecurity measures for importation of nursery stock into New Zealand date back to 1889, when fumigation vaults were constructed, according to Helson (1966). Since as early as 1966, imported plants were inspected at the New Zealand border and fumigated with methyl bromide if any pests were detected (Helson 1966). Post inspection and treatment the plants were placed in post-entry quarantine for 12 months and all plants showing disease symptoms during this period were destroyed. Since 1993, importations of avocado plant material have been subject to additional biosecurity measures imposed by the Ministry for Primary Industries Standard 155.02.06 Importation of Nursery Stock issued as an import health standard pursuant to section 24A of the Biosecurity Act 1993 (MPI 2014). These measures along with improved diagnostic techniques are likely the reason there have been no new records of avocado diseases since 1991.

Diseases of avocado not found to date in New Zealand are: avocado sunblotch viroid (ASBVd); avocado scab (Sphaceloma perseae); cercospora spot (Pseudocercospora purpurea); laurel wilt (Raffaelea lauricola); fusarium dieback (Fusarium sp.); and Phellinus noxius.

An early record of $S$. perseae (avocado scab) in New Zealand (Hartill 1991a), was disproved by Everett et al. (2011), following re-examination and pathogenicity tests of the specimens deposited in the Manaaki Whenua Landcare Research Herbarium and International Collection of Microorganisms from Plants (ICMP). A record of ASBVd detected in 1999 by the Ministry of Agriculture and Forestry (MAF) was also disproven following a joint avocado industry and MAF biosecurity survey conducted during 2009 (Pugh \& Thomson 2009).
The aim of this study was to collate relevant information on serious avocado pathogens not currently present in New Zealand and their potential impact to the New Zealand avocado industry if they were to establish in avocadogrowing regions of the country.

\section{METHODS}

An electronic literature search of Web of Science, CABI and Google databases was conducted on 2 February 2018 using the terms avocado or Persea AND fung* or plant and pathogen ${ }^{\star}$. Resultant publications were obtained and the literature listed in those papers was used to access literature beyond the scope of the electronic searches. References in the first author's collection were also accessed. The Manaaki Whenua Landcare database (www.landcareresearch.co.nz) was accessed to determine what pathogens were not present in New Zealand. Only those avocado pathogens not previously reported in $\mathrm{New}$ Zealand that are considered to have the potential to become a serious problem if they establish are included. These decisions were made according to an examination of the publications and the authors' expert opinion.

\section{RESULTS}

Over 70 papers were selected as a result of the above search. Information on current disease range, hosts, infection pathways and possible impact if established in New Zealand is presented for each organism.

\section{Avocado sunblotch viroid (ASBVd)}

ASBVd is reported to be present in Israel, Ghana, South Africa, Spain, Mexico, the United States of America (USA; California, Florida), Peru, Costa Rica, Guatemala, Venezuela and Australia (CABI 2014b; EPPO 2016).

ASBVd is known to naturally infect only one host, Persea americana (avocado). Under experimental conditions, however, ASBVd was transmitted to plants of other members of the Lauraceae family using a bark-patch grafting technique (da Graca \& van Vuuren 1980; da Graca \& van Vuuren 1981a). 
The main problems associated with this disease are disease management costs, such as those required to ensure nursery material is not infected, destroying infected trees in the orchard showing symptoms, tests for detection of asymptomatic infected trees, and yield reduction. Presence of ASBVd can also restrict access to some markets, such as the restriction of imports from eight countries with records of ASBVd by Costa Rico in 2015 (Anonymous, 2015). ASBVd causes skin distortions and chlorotic patches rendering the disfigured avocados unmarketable. ASBVd affects leaves and shoots similarly, causing distortions and chlorotic patches. ASBVd can also infect asymptomatically, depending on the host cultivar, environmental conditions and viroid strain (Saucedo-Carabez et al. 2014). Infected trunk bark can have a scaly appearance referred to as 'crocodile' bark. A study by da Graca et al. in 1983 found the effect of ASBVd-infection on the overall crop was severe resulting in over half the harvested fruit downgraded due to poor quality (although the overall reduction in yield was only 30\%). Desjardins et al. (1987) found the yield of fruit from ASBVd-infected trees may be reduced by as much as 95\%. More recently, SaucedoCarabez et al. (2014) reported the yield of 'Hass' was reduced by $75 \%$ in symptomatic trees and $30 \%$ in symptomless trees. Trees can be stunted and growing points can die back. ASBVd can also cause premature leaf and flower fall. The main pathways of transmission of ASBVd are through the use of graft material during propagation and infected seed used for rootstocks. However, natural disease transmission can occur by root grafting. Mechanical transmission is rare although ASBVd can be spread on sap-contaminated tools (e.g. injection equipment, pruning saws and clippers). Desjardins et al. (1979) reported a low rate of spread caused by infected pollen carried by bees (1-4\%). In that study, the pollen caused infection of developing fruit without the trees being affected (Desjardins et al. 1987). Trees were indexed for sunblotch infection by grafting with a viroid free scion. Infected seed used for rootstocks taken from symptomless trees, can result in outbreaks of sunblotch (Desjardins et al. 1984). Seed transmission from 'recovered' or symptomless trees can be as high as $95 \%$ (Wallace \& Drake 1962). Spread by seed from fruit developing from flowers pollinated with infected pollen (5\%) was higher than from the pollen itself (1-4\%) (Wallace \& Drake 1962).

Foliar symptoms are more pronounced with increased temperature (da Graca \& van Vuuren 1981b) suggesting an adaptation to hot climates. Although New Zealand has a relatively cool climate, the viroid is expected to survive wherever avocado trees grow (Perez et al. 2017). Therefore, the disease could establish where avocados are grown in New Zealand, in the Northland, Whangarei, Bay of Plenty, Hawke's Bay and Nelson districts.

\section{Avocado scab (Sphaceloma perseae)}

Sphaceloma perseae is listed in the Crop Protection Compendium (CABI 2014a) as present in the Philippines, Taiwan, Guinea, Morocco, South Africa, Zambia, Zimbabwe, Bermuda, Mexico, USA (Florida, Texas), Barbados, Costa Rica, Cuba, Dominica, Dominican Republic, El Salvador, Guadeloupe, Guatemala, Haiti, Honduras, Jamaica, Nicaragua, Panama, Puerto Rico, Argentina, Brazil (Espirito Santo, Rio Grande do Sul), Guyana, Peru and Venezuela.

Avocado scab causes superficial cosmetic damage to fruit, reducing its marketability. Crop losses of up to $53 \%$ have been reported (Vidales 1996). Lesions may also affect leaves, but reduction in yield from leaf infection has not been reported. The most important impact if it established in New Zealand would be a restriction of market access for New Zealand avocados to countries or regions that do not have this disease such as Australia, Europe and USA (California) (Everett et al. 2011).

Scab symptoms can be similar to physical damage caused by other means, such as wind rub. Characteristic symptoms of scab are circular lesions on the surface of the fruit that can converge into larger areas of rough corky tissue, circular lesions on the peduncles, and 'scabby', hard, protruding, circular lesions on the underside of the leaves. Leaf symptoms are difficult to find 
through basic field monitoring as infections are mostly in the top of the canopy (Palmateer 2006). A DNA test for avocado scab is available for nursery plants and fruit (Everett et al. 2011). Movement of infected nursery plants probably presents the highest risk of spreading avocado scab. Plant material for propagation can only be imported into New Zealand as dormant cuttings or tissue cultures. Imported material must also be grown in a post-entry quarantine facility for 12 months and inspected regularly for symptoms. This level of inspection would be expected to detect new infections and any existing lesions on the trunk or twigs thus minimising the risk of importation of avocado scab by this pathway. The Import Health Standard (IHS) for fresh fruit into New Zealand allows imports only from Australia and Tonga (MAF 2014), which are not known to have avocado scab so the risk of importing avocado scab on fruit through this commercial pathway is low. Infected mature fruit probably represent a low risk as most sporulation occurs up to 2-3 months after fruit set (Palmateer 2006). Avocado seeds are not likely to be contaminated with avocado scab, because, as far as is known, it is not seed transmitted.

Avocado scab produces spores on fruit, leaves and twigs during the early stages of infection. Spores are spread by rain and wind but also on contaminated equipment (e.g. pruning saws, clippers, leaves caught on hydra-ladders, picking bags and fruit bins) and by leaf material contaminating workers' clothing.

Avocado is the only known host of avocado scab (Jenkins 1934) so establishment in New Zealand would be limited to avocado trees in orchards, public places and home gardens. Infection occurs at temperatures between 10 and $26^{\circ} \mathrm{C}$ (Marroquin-Pimentel 1999; Vidales et al. 1999; Marroquin-Pimentel 2000). Fruit are susceptible to infection immediately after set until reaching a size of 20-29(W) x 24-39 (H) mm (Avila-Quezada et al. 2003), or until half size (about $30(\mathrm{~W})$ x $50(\mathrm{H}) \mathrm{mm}$ ) (Pernezny \& Marlatt 2007). Young leaves are also susceptible to infection, but become resistant after a month (Pernezny \& Marlatt 2007). Twigs, peduncles and petioles may also be infected during spring and early summer (Palmateer 2006). Temperatures in avocado-growing districts of New Zealand are usually within the range suitable for infection during fruit set and early growth (HortPlus 2018). The conidia of the closely related citrus scab fungus, Elsinoë fawcettii, required 1.5-2.5 hours in free water to germinate and infect citrus (Whiteside 1975). Infection can occur during periods of rain or heavy morning dew, both of which are frequent during the period of fruit susceptibility in New Zealand (HortPlus 2018). Humidity had no effect on disease progress even when it was as low as $30 \%$ (Marroquin-Pimentel 1998), and is unlikely to be a limiting factor for infection in New Zealand.

\section{Cercospora spot (Pseudocercospora purpurea)}

Pseudocercospora purpurea is listed in the Crop Protection Compendium (CABI 2014d) as being present in India (Sikkim), Japan, Philippines, Cameroon, Congo Democratic Republic, Côte d'Ivoire, Guinea, Kenya, South Africa, Bermuda, Mexico, USA (Florida, Georgia, Mississippi) Dominica, El Salvador, Honduras, Jamaica, Nicaragua, Panama, Puerto Rico, Trinidad and Tobago, United States Virgin Islands Argentina, Bolivia, Brazil, (Sao Paulo), Chile, Guyana, Peru, Venezuela and Palau. There are also records of cercospora spot in Australia (Peterson \& Grice 1992), Costa Rica, Cuba, Dominican Republic, Guadeloupe, Guatemala and USA (Hawaii, south-eastern states) (Crous \& Braun 2003).

Fruit losses due to cosmetic damage can be up to $69 \%$ in unsprayed orchards in South Africa (Darvas \& Kotze 1987). All commercial cultivars of $P$. americana are affected (Chupp 1954; Crous \& Braun 2003). In Tzaneen, South Africa, commercial losses from sprayed orchards over a 6 -year period ranged from 0 to $12 \%$ for 'Fuerte, 'Edranol', 'Hass' and 'Ryan' cultivars (Darvas 1982).

Characteristic symptoms on leaves are angular leaf spots, initially 1-2 mm diameter surrounded by a small yellow halo that first appears on the lower side of mature to older leaves. Spots eventually appear on the top surface of leaves 
and coalesce to form large brown patches. On immature fruit, the first symptoms are small (c. 3 $\mathrm{mm}$ ) greenish-white, superficial blemishes. Once fruit are mature, the disease is characterised by slightly sunken brown blotches (c. $<6 \mathrm{~mm}$ ) that may coalesce and form small surface cracks (Pegg et al. 2002).

Spores are released and spread by rainfall from infected fruit, leaves and stems. Fruit are most susceptible to infection in early summer, and spores are more difficult to isolate from lesions as they age. Spores may be spread on contaminated equipment and by leaf material (Dann et al. 2013).

A relationship between spore release, temperature and humidity was described by Darvas (1982). Spore release was highest at $18^{\circ} \mathrm{C}$ and declined gradually as temperatures increased to $25^{\circ} \mathrm{C}$ (the lowest and highest temperatures measured respectively). Spore release was positively correlated with humidity up to $84 \%$. Temperatures during early spring are generally lower than $18^{\circ} \mathrm{C}$ in the avocado-growing districts of New Zealand (HortPlus 2018). In the Tzaneen region of South Africa, most infections occurred between November and January but the temperature minima and maxima for infection were not determined (Darvas 1982). After March, no new infections were recorded (Darvas 1982), presumably because the temperatures were too low for infection to occur. Precipitation occurs throughout the year with the highest rainfall in January (182 $\mathrm{mm}$ average) and the lowest in July (10 $\mathrm{mm}$ average) (https://en.climate-data.org/ location/15345/); thus, rainfall is unlikely to limit infection. Monthly average temperatures in New Zealand (Fig. 1) suggest that the temperatures may be too low for the establishment of this disease.

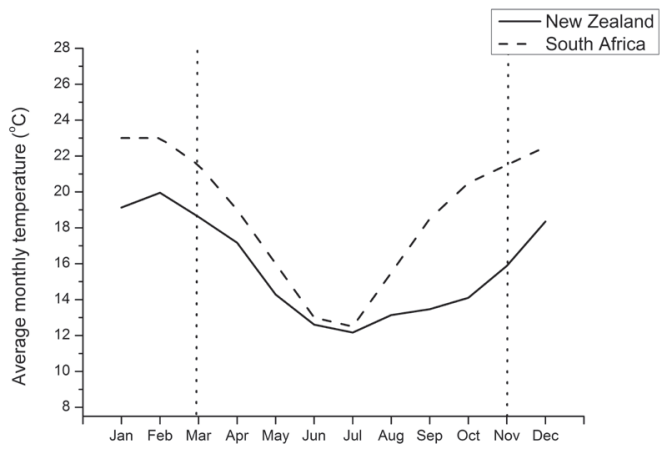

Figure 1 Average monthly temperatures for Tzaneen, South Africa and Northland, New Zealand. Data from http://www.meoweather. $\mathrm{com} / \mathrm{h}$ (South Africa) and from MetWatch Online (HortPlus 2018) (New Zealand).

\section{Laurel wilt (Raffaelea lauricola)}

The fungus Raffaelea lauricola is listed in the CABI Crop Protection Compendium (CABI 2014c) as present in some eastern states of the USA (Alabama, Florida, Georgia, Mississippi, South Carolina).

Hosts are members of the Lauraceae family, including Persea americana (Mayfield et al. 2008), Cinnamomum camphora (camphor laurel), Litsea sp., Persea borbonia (bay laurel), Persea humilis (silk bay), Sassafras albidum (common sassafras) (CABI 2014c).

Laurel wilt affects avocados causing wilting of terminal leaves that then turn brown. Wilting can be branch specific, with some branches unaffected. Avocado leaves defoliate 2-3 months after the onset of symptoms. Affected avocado sapwood is stained reddish brown to bluish grey (Ploetz et al. 2012). Eventually, the entire tree dies over a period of weeks to several months (Evans et al. 2010). These same authors estimated economic losses from laurel wilt in Florida based on a \$US30M per annum industry, reductions in property values and increased management costs. If laurel wilt were to affect $50 \%$ of trees in Florida, the estimated cost would be $\$$ US182M, and $\$$ US271M if $75 \%$ of trees were affected. 
These figures assume property value declines as well as direct loss of income.

The vector, Xyleborus glabratus (redbay ambrosia beetle), has historically been reported to only invade dead trees of several plant families (including Lauraceae, Dipterocarpaceae, Fagaceae and Fabaceae) in its natural habit (Rabaglia et al. 2006). However, only since arriving in the south-eastern USA (SE USA), has this beetle been reported to infest live trees. In 2003, large stands of bay laurel were observed to wilt and die. Mortality was shown to have resulted from infestation by $X$. glabratus, followed by pathogenesis by the fungal pathogen $R$. lauricola (Fraedrich et al. 2008). The insect vector was able to infest live plants of common sassafras, swamp bay (Persea palustris), camphor laurel, silk bay, gulf licaria (Licaria trianda), pondberry (Lindera melissifolia) and pondspice (Litsea aestivalis) which were then killed by the fungus (Fraedrich et al. 2008; Smith et al. 2009; Fraedrich et al. 2011; Hughes et al. 2011; Hughes et al. 2012; Bates et al. 2013; Ploetz \& Konkol 2013). Most members of the Lauraceae family that have been tested are susceptible to laurel wilt (Pena et al. 2012). Camphor laurel is the only one of these host species present in New Zealand (Allan Herbarium 2000). However, there are several additional native and ornamental members of the Lauraceae family that are likely hosts, including tawa and taraire (Beilschmiedia tawa and B. tarairi).

The first detection of the vector in USA was in 2002. The spread of laurel wilt has exceeded that predicted in models (Koch \& Smith 2008), possibly because of human-assisted spread of infected logs as firewood throughout the SE USA. In Florida, laurel wilt spread at the rate of 32-48 km per year (Evans et al. 2010). Laurel wilt took 10 years from the first detection in 2002 to invade commercial avocado orchards (Kendra et al. 2013).

Both the insect vector and the fungus survive in tunnels burrowed into wood of a suitable host. As the wood decays, the available nutrients for the fungus decline, until eventually the pathogen is replaced by saprotrophs. During colonisation of the living tree by the redbay ambrosia beetle, the fungus produces conidia formed in fruiting structures called sporodochia, upon which both the beetle and its larvae feed. The beetle carries fungal spores from tree-to-tree in specialised pouches called mycangia. The fungi multiply inside these mycangia in a yeast phase, nourished by secretions from surrounding gland cells (Fraedrich et al. 2008; Harrington et al. 2011).

No studies on the temperature range required for survival and reproduction of $R$. lauricola were found in the literature examined. The modelling of the spread of this fungus in the SE USA used temperature parameters determined for the vector, based on the described range in its native habitat (India, southern Japan, Myanmar and Taiwan) (Koch \& Smith 2008). According to that model, the climate of coastal areas in the SE USA was suitable for the establishment and spread of the insect. The climate in both the natural habitat and in the SE USA is warmer than in New Zealand; therefore, it is possible that the beetle would not be ideally suited to the New Zealand climate, reducing chances of successful establishment and spread.

\section{Fusarium dieback}

Fusarium euwallaceae (Freeman et al. 2013) is vectored by ambrosia beetles in the Euwallaceae fornicatus species complex (Na et al. 2018). These beetles are morphologically indistinguishable, and can only be identified by sequencing the mitochondrial cytochrome oxidase I (COI) locus by which they have been assigned the names polyphagous shothole borer (Euwallacea sp. nr. fornicatus \#1, PSHB) (Eskalen et al. 2013; O'Donnell et al. 2015) and Kuroshio shot hole borer (Euwallacea sp. nr. fornicatus \#5, KSHB) (O’Donnell et al. 2015; Stouthamer et al. 2017) in California. Euwallacea nr. fornicatus found in avocado trees in Israel (Mendel et al. 2017) was in the same clade as PSHB (Stouthamer et al. 2017) and is Euwallacea sp. nr. fornicatus \#1.

This fungus and its associated ambrosia beetle vectors have been described as causing a serious dieback disease in Israel (Mendel et al. 2012; Mendel et al. 2017) and California (Eskalen 
et al. 2012). Further examination has shown that molecular phylogenetics distinguishes six morphologically identical clades of $F$. euwallaceae, of which at least four attack and reproduce in avocado (O'Donnell et al. 2016). In addition to F. euwallaceae, found in Israel and the Los Angeles basin of Southern California, there are at least a further four unnamed Fusarium species; Fusarium sp. AF-6 and AF-8 in MiamiDade County, Florida; Fusarium sp. AF-7 in Queensland, Australia; and Fusarium sp. AF-12 in San Diego and Orange Counties, California (O'Donnell et al. 2015). The Kuroshio shothole beetle (KSHB) has been shown to vector Fusarium sp. AF-12 (Dodge et al. 2017). These other associations cause less damage than F. euwallaceae and PSHB (Kasson et al. 2013) although more recent reports are that KSHB and Fusarium sp. AF-12 also cause a severe dieback disease in San Diego county and Northern Mexico (Dodge et al. 2017). KSHB has also been found in Santa Barbara and San Luis Obispo Counties. Recently, F. euwallaceae and PSHB have been reported for the first time attacking Platanus $\times$ acerifolia in the KwaZulu/Natal National Botanical Gardens in South Africa (Paap et al. 2018). Two other fungi (Paracremonium pembeum and Graphium euwallaceae) have been associated with fusarium dieback, and on inoculated shoots of avocado $P$. pembeum produced larger lesions than both F. euwallaceae and G. euwallaceae (Lynch et al. 2016).

Naturally spread F. euwallaceae has been found causing symptoms on 112 tree species in 40 families in botanical gardens in California (Eskalen et al. 2013), and in Israel 52 tree species from 26 botanical families (Mendel et al. 2017). Families with the highest number of infected species were the Aceraceae, Fabaceae and Fagaceae.

Only 19 species were reproductive hosts for PSHB (Acer buergerianum, A. macrophyllum, A. negundo, A. palmatum, A. paxii, Ilex cornuta, Ricinus communis, Albizia julibrissin, Castanospermum australe, Cercidium floridum, C. $\times$ sonorae, Erythrina corallodendron, Parkinsonia aculeata, Quercus agrifolia, Q. robur, Liquidambar styraciflua, Persea americana, Platanus racemosa, Camellia semiserrata); death of mature trees was observed for three of these (Q. robur, A. negundo and R. communis) (Eskalen et al. 2013). A further eight reproductive hosts were found in Israel (Quercus ithaburensis, Q. calliprinos, Q. pedunculiflora, Morus alba, Platanus occidentalis, P. orientalis, Acer obutsifolium, A. pseudopltanus (Mendel et al. 2017).

Avocado trunks attacked by PSHB exhibit 'sugar volcanoes' consisting of perseitol, a polyol, and possibly its 7-carbon sugar form D-mannoheptulose (Minchin et al. 2015). Excretions 1-15 cm in diameter and 0.5-5 $\mathrm{cm}$ high surround entry holes (Eskalen et al. 2013). Exit holes surrounded by small tubes of compacted sawdust can be seen after the emergence of adults (Mendel et al. 2012).

Initial trunk infection is followed by wilting of branches and discolouration of leaves, wilting and collapse of heavily bearing branches. PSHB constructs its galleries in xylem, thus growth of the fungal symbiont can obstruct water transport causing wilting and dieback of the host tree (Freeman et al. 2013). Large branches are not as seriously affected, thus only small diameter branches exhibit severe symptoms. Tree mortality has been reported (Freeman et al. 2012), presumably of small trees. Fusarium euwallaceae survives in mycangia (small sacs) of the PSHB (Freeman et al. 2012a), and, if similar to other fungi vectored by ambrosia beetles, is nurtured there in a yeast form by secretions from gland cells of the insect (Fraedrich et al. 2008; Harrington et al. 2011). The fungus also survives in infected plants within galleries made by the PSHB.

In Israel, the major commercial avocado cultivars 'Hass', 'Pinkerton' and 'Ettinger' were attacked by the vector and the fungus, with 'Hass' being the most susceptible. The fungus had been isolated from trees on 15 grower properties in the coastal plain of central Israel by 2012 (Freeman et al. 2012b). The beetle-fungus complex has become a serious threat to the avocado industry in that country (Freeman et al. 2012b; Mendel et al. 2012). 
PSHB was first collected from several tree species in California in 2003 without an associated disease. An associated Fusarium sp. disease was first observed in backyard avocado trees and woody ornamentals in 2012. By 2013, F. euwallaceae. was recovered from 54\% (207 out of 335) of trees found to be infested by PSHB during an intensive survey of two botanical gardens adjacent to the first sighting of PSHB (Eskalen et al. 2013). Fusarium euwallaceae is primarily spread by the vector, which flies from tree to tree, and by human-assisted movement of affected wood.

Both Israel and California have warmer summers than New Zealand, but winter mean daily temperatures are similar (Te Puke, c. $9^{\circ} \mathrm{C}$, Metwatch Online (HortPlus 2018); Ventura County California c. $12^{\circ} \mathrm{C}$, http://www.usa.com/ ventura-county-ca-weather.htm; Israel coastal plains $12^{\circ} \mathrm{C}$, eastern valleys $13^{\circ} \mathrm{C}$ (Homsky 1995). Because winter temperatures are those that affect the range of ambrosia beetles (Formby 2014), it will be necessary to determine if the $\mathrm{c} .3^{\circ} \mathrm{C}$ lower mean monthly temperature is critical to the survival of Euwallacea spp. in order to estimate likely establishment risk in New Zealand.

\section{Phellinus noxius (Brown root rot)}

Phellinus noxius is listed in the CABI Crop Protection Compendium (2014a) as being present in China, India (Assam, Karnataka, Kerala, Tamil Nadu, Tripura, Uttar Pradesh), Indonesia (Java, Sumatra), Japan (Ryukyu Archipelago), Malaysia (Peninsular Malaysia, Sabah, Sarawak), Myanmar, Pakistan, Philippines, Singapore, Sri Lanka, Taiwan, Vietnam, Angola, Benin, Burkina Faso, Cameroon, Central African Republic, Congo Democratic Republic, Côte d'Ivoire, Gabon, Ghana, Kenya, Nigeria Sierra Leone, Tanzania, Togo, Uganda, Costa Rica, Cuba, Puerto Rico, American Samoa, Australia (New South Wales, Queensland), Fiji, Micronesia, Niue, Northern Mariana Islands, Papua New Guinea, Samoa, Solomon Islands and Vanuatu.

Phellinus noxius has a wide host range, affecting 200 tree species belonging to 59 families, including Persea americana (Ann et al. 2002),
Acacia confusa, Araucaria cunninghamii (hoop pine), Bauhinia variegata (mountain ebony), Calophyllum inophyllum (Alexandrian laurel), Camellia sinensis (tea), Casuarina equisetifolia (casuarina), Coffea sp. (coffee), Ficus microcarpa (Indian laurel tree), Garcinia mangostana (mangosteen), Podocarpus macrophyllus (longleaf podocarpus), Salix babylonica (weeping willow), Tectona grandis (teak) and Theobroma cacao (cocoa) (CABI 2014a).

Phellinus noxius causes considerable losses to avocado growers in Taiwan every year (Ann et al. 2002) while rows of dead avocado trees were first noticed in Queensland, Australia in 2001 (Dann et al. 2009). Examination of the collar of dead trees in Queensland revealed a 'stocking' of brown mycelium extending up the trunk, binding together twigs, soil, and stones, sometimes with a white margin. Eventually the 'stocking' turned black. The wood beneath the stocking was brown with white patches. A survey in Queensland (Australia) during 2007-2009 found P. noxius in $17 / 18$ properties on the Atherton Tableland, $3 / 5$ in the Childers/Bundaberg area, and one orchard at Maleny. Two orchards in northern New South Wales were also affected. Of the 23 infected properties surveyed, about $10 \%$ of trees died on four severely affected orchards, with an estimated economic loss of \$AUD5400/ha. If left unmanaged, loss of an entire orchard is possible (Dann et al. 2009).

Phellinus noxius produces air-borne basidiospores in bracket fungi type fruiting structures, which can be dispersed widely. Basidiospores infect wounded tissue such as pruning wounds and cut-off stumps. In Australia, these fruiting structures have not been observed on avocados, but the epidemic may have been started by basidiospores from infected native trees adjacent to the avocado orchards. Tree-totree spread is by root contact with adjacent trees (Ann et al. 2002; Dann et al. 2009).

The fungus does not survive or spread at low temperatures. The optimal temperature for mycelial growth is above $30^{\circ} \mathrm{C}$ and there was no growth at $8^{\circ} \mathrm{C}$. This thermal range could explain the restriction of $P$. noxius to tropical 
and sub-tropical climates. In Taiwan, the disease is not found at elevations $>1000 \mathrm{~m}$ despite the availability of susceptible host species, presumably because it is too cold for the fungus to grow, infect or survive (Ann et al. 1999; Ann et al. 2002).

\section{DISCUSSION}

ASBVd infects avocados in a number of countries with climates similar to New Zealand so there is a high risk of it establishing in New Zealand. Of particular concern is its possible importation in fruit from symptomless plants or seeds. New Zealand only imports fresh avocados from areas free of ASBVd in Australia and from Tonga which does not have ASBVd, yet this pathway remains a risk as more fruit imports from other countries are likely to be considered in the future. Avocado seed for sowing can only be imported from the USA, which does report the presence of ASBVd. The measures specified in the IHS (MPI 2018) must be strictly adhered to ensure that ASBVd is not introduced. Illegal imports of seed for rootstocks or fruit from infected regions are probably the pathways with the most risk of introducing ASBVd into New Zealand. The industry's High Health Scheme also requires avocado nurseries to undertake ASBVd testing of the plants they propagate as an early-warning disease-screening programme.

Environmental parameters suitable for infection by avocado scab are found where avocados are grown in New Zealand, and there is a high likelihood of establishment. There are few commercial trade pathways for this pathogen, yet the risk remains so industry vigilance and crop monitoring must continue. Industry vigilance consists of formal crop monitoring by accredited pest monitors through the AvoGreen ${ }^{\otimes}$ programme (Anonymous 2018) and is mandatory for all export registered orchards. Many of these trained pest scouts are also part of the industry's First Detector Network that encourages early reporting of unusual pest and disease observations. The regular distribution of exotic pest and disease awareness material to growers also helps promote the importance of detecting and reporting disease symptoms early.

Laurel wilt and fusarium dieback are both new, emerging diseases. Laurel wilt is the most aggressive and incursive plant pathogen of avocados recorded worldwide. The current distribution of the fungi causing laurel wilt and fusarium dieback is in climates warmer than New Zealand but there is still a risk that they could establish here, especially if New Zealand becomes warmer due to climate change. Usually ambrosia beetles attack declining or dead trees (Na et al. 2018). Both these diseases are vectored by ambrosia beetles that attack healthy trees. It has been hypothesised that this is the effect of vectors being exposed to naïve and new hosts, which produces confusing olfactory cues and results in invasion of healthy tissue (Mendel et al. 2017). Thus, the establishment of these vectors could have unexpected outcomes for the native vegetation of New Zealand such as new hosts being attacked.

Brown root rot and cercospora spot are less likely than ASBVd or avocado scab to establish in the relatively cool New Zealand climate. However, the climate in Northland can experience above-average temperatures as can various microclimates in other avocado production areas in New Zealand so any potential for establishment needs to be confirmed experimentally or with the use of predictive models before firm conclusions can be made.

\section{CONCLUSIONS}

Avocado exports were worth $\$ 147.5$ million to the New Zealand economy in the 2016 season, of which $\$ 125$ million was earned from the Australian market (Aitkin \& Warrington 2017). If avocado scab were to establish in New Zealand, this lucrative market could be at risk, because $S$. perseae is not present in Australia. The main impact of laurel wilt, fusarium dieback and Phellinus noxius would be on avocado yields because none of these diseases infect fruit. The cost of yield losses, monitoring, removal and destruction of infected trees if these diseases establish in New Zealand is likely to be expensive. If ASBVd were to establish in New Zealand the 
avocado industry as at risk of yield losses, the cost of control and restricted market access. It is estimated that $50 \%$ tree losses due to any of these diseases or their control would cost the New Zealand economy over $\$ 100$ million, and 75\% tree losses could reduce industry value by $\$ 150$ million. Such impacts would decimate the New Zealand avocado industry.

\section{REFERENCES}

Aitken AG, Warrington IJ 2017. FreshFacts. New Zealand Horticulture. Plant \& Food Research, Auckland, New Zealand. 42 p. www.freshfacts.co.nz.

Allan Herbarium 2000. Nga Tipu o Aotearoa New Zealand Plant Names Database. http:// nzflora.landcareresearch.co.nz/ (accessed 7 February 2018).

Ann PJ, Chang TT, Ko WH 2002. Phellinus noxius brown root rot of fruit and ornamental trees in Taiwan. Plant Disease 86: 820-826.

Ann PJ, Lee HL, Huang TC 1999. Brown root rot of 10 species of fruit trees caused by Phellinus noxius in Taiwan. Plant Disease 83: 746-750.

Anonymous 2015. Costa Rico bans Mexican, Guatamalen avocados. The Packer. July 27. https://www.thepacker.com/article/costarica-bans-mexican-guatemalan-avocados

Anonymous 2018. AvoGreen Manual. Version 6.3. February 2018. www.nzavocado.co.nz. 33 p.

Avila-Quezada GD, Teliz-Ortiz D, Mora-Aguilera G, Vaquera-Huerta $H$, Tijerina-Chavez L 2003. Spatial and temporal dynamic of scab (Sphaceloma perseae Jenk.) on avocado (Persea americana Mill.). Revista Mexicana de Fitopatologia 21: 152-160.

Bates CA, Fraedrich SW, Harrington TC, Cameron RS, Menard RD, Best GS 2013. First report of laurel wilt, caused by Raffaelea lauricola, on sassafras (Sassafras albidum) in Alabama. Plant Disease 97: 688.

Boesewinkel HJ 1982. A list of 142 new plant disease recordings from New Zealand and short notes on three diseases. Australasian Plant Pathology 11: 40-43.

Brien RM 1939. A list of plant disease recorded in New Zealand. Bulletin of the New Zealand Department of Scientific and Industrial Research 67. 39 p.

CABI 2014a. Phellinus noxius. Crop Protection Compendium. $\mathrm{CAB}$ International. Wallingford, UK. www.cabi.org/cpc.

CABI 2014b. Avocado sunblotch viroid. CAB International. Wallingford, UK. www.cabi. org/cpc

CABI 2014c. Raffaelea lauricola. Crop Protection Compendium. CAB International. Wallingford, UK. www.cabi.org/cpc.

CABI 2014d. Pseudocercospora purpurea (spot blotch). Crop Protection Compendium. CAB International, Wallingford, UK. www.cabi. org/cpc.

Chupp C 1954. A monograph of the fungus genus Cercospora. published by the author, Ithaca, New York.

Crous PW, Braun U 2003. Mycosphaerella and its anamorphs. 1. Names published in Cercospora and Passalora: Mycosphaerella and its anamorphs. CBS Biodiversity Series No. 1. Centraalbureau voor Schimmelcultures, Utrecht, The Netherlands. 571 p.

da Graca JV, van Vuuren SP 1980. Transmission of avocado sunblotch disease to cinnamon. Plant Disease 64: 475.

da Graca JV, van Vuuren SP 1981a. Host range studies on avocado sunblotch. South African Avocado Growers' Association Yearbook 4: 80.

da Graca JV, van Vuuren SP 1981b. Use of high temperature to increase the rate of avocado sunblotch symptom development in indicator seedlings. Plant Disease 65: 46-47.

da Graca JV, Mason TE, Antel HJ 1983. Effect of avocado sunblotch disease on fruit yield. South African Avocado Growers' Association Yearbook 6: 86-87.

Dann E, Smith L, Pegg K, Grose M, Pegg G 2009. Report on Phellinus noxius, the cause of brown rot, in Australian avocados. Talking Avocados 20: 28-34.

Dann EK, Ploetz RC, Coates LM, Pegg KG 2013. Foliar, fruit and soilborne diseases. In: Whiley AW, Schaffer B, Wolstenholme BN, Albert 
VA, Aluja $\mathrm{M}$ eds. The Avocado: Botany, Production and Uses. CABI, Wallingford. Pp. 380-422.

Darvas J 1982. Etiology and control of some avocado fruit diseases. DSc (Agric) thesis, University of Pretoria, Pretoria, South Africa. $136 \mathrm{p}$.

Darvas JM, Kotze JM 1987. Avocado fruit diseases and their control in South Africa. Yearbook, South African Avocado Growers' Association 10: 117-119.

Desjardins PR, Drake RJ, Atkins EL, Bergh BO 1979. Pollen transmission of avocado sunblotch virus experimentally demonstrated. California Agriculture 33: 14-15.

Desjardins PR, Drake RJ, Sasaki PJ, Atkins EL, Bergh BO 1984. Pollen transmission of avocado sunblotch viroid and the fate of the pollen recipient tree. Phytopathology 74: 845.

Desjardins PR, Saski PJ, Drake RJ 1987. Chemical inactivation of avocado sunblotch viroid on pruning and propagation tools. California Avocado Society Yearbook 71: 259-262.

Dodge C, Coolidge J, Cooperband M, Cosse A, Carrillo D, Stouthamer R 2017. Quercivorol as a lure for the polyphagous and Kuroshio shot hole borers, Euwallacea spp. nr. fornicatus (Coleoptera: Scolytinae), vectors of Fusarium dieback. Peerj 5.

EPPO 2016. Avocado sunblotch viroid (ASBVDO). https://gd.eppo.int/taxon/ ASBVD0/distribution (accessed 17 April 2018).

Eskalen A, Gonzalez A, Wang DH, Twizeyimana M, Mayorquin JS, Lynch SC 2012. First report of a Fusarium sp. and its vector Tea Shot Hole Borer (Euwallacea fornicatus) causing Fusarium dieback on avocado in California. Plant Disease 96: 1070.

Eskalen A, Stouthamer R, Lynch SC, RugmanJones PF, Twizeyimana M, Gonzalez A, Thibault $\mathrm{T}$ 2013. Host range of fusarium dieback and its ambrosia beetle (Coleoptera: Scolytinae) vector in Southern California. Plant Disease 97: 938-951.

Evans EA, Crane J, Hodges A, Osborne JL 2010. Potential economic impact of laurel wilt disease on the Florida avocado industry. HortTechnology 20: 23-238.

Everett KR, Stevens PS, Cutting JGM 1999. Postharvest fruit rots of avocado are reduced by benomyl applications during flowering. Proceedings / New Zealand Plant Protection conference 52: 153-156.

Everett KR, Rees-George J, Parkes SL, Johnston PR 2003. Predicting avocado fruit rots by quantifying inoculum potential in the orchard before harvest. Proceedings V World Avocado Congress (Actas V Congreso Mundial del Aguacate): 601-606.

Everett KR, Rees-George J, Pushparajah IPS, Manning MA, Fullerton RA 2011. Molecular identification of Sphaceloma perseae (Avocado $\mathrm{Scab}$ ) and its absence in New Zealand. Journal of Phytopathology 159: 106-113.

Fletcher WA 1976. Avocado growing in New Zealand. Orchardist of New Zealand 49: 220228.

Formby JP 2014. Potential range of ambrosia beetle based on temperature range. http:// www.dontmovefirewood.org/potentialrange-ambrosia-beetle-based-temperaturerange.html (accessed 10 February 2018).

Fraedrich SW, Harrington TC, Rabaglia RJ, Ulyshen MD, Mayfield AE, III, Hanula JL, Eickwort JM, Miller DR 2008. A fungal symbiont of the redbay ambrosia beetle causes a lethal wilt in redbay and other Lauraceae in the southeastern United States. Plant Disease 92: 215-224.

Fraedrich SW, Harrington TC, Bates CA, Johnson J, Reid LS, Best GS, Leininger TD, Hawkins TS 2011. Susceptibility to laurel wilt and disease incidence in two rare plant species, pondberry and pondspice. Plant Disease 95: 1056-1062.

Freeman S, Protasov A, Sharon M, Mohotti K, Eliyahu M, Okon-Levy N, Maymon M, Mendel Z 2012a. Obligate feed requirement of Fusarium sp. nov., an avocado wilting agent, by the ambrosia beetle Euwallacea aff. fornicata. Symbiosis 58: 245-251.

Freeman S, Protasov A, Wysoki M, Yehuda B, Noi M, Rabaglia R, O’Donnell K, Sharon 
M, Okon-Levy N, Zveibil A, Eliyahu M, Mendel Z 2012b. A pernicious agent affecting avocado in Israel: a novel symbiotic Fusarium sp. associated with the ambrosia beetle Euwallacea fornicatus. Phytoparasitica 40: 258.

Freeman S, Sharon M, Maymon M, Mendel Z, Protasov A, Aoki T, Eskalen A, O'Donnell $\mathrm{K}$ 2013. Fusarium euwallaceae sp. nov.-a symbiotic fungus of Euwallacea sp., an invasive ambrosia beetle in Israel and California. Mycologia 105: 1595-1606.

Green GA 1927. Notes on the avocado in New Zealand. California Avocado Association Yearbook 12: 39-40.

Harrington TC, Yun HY, Lu S, Goto H, Aghayeva DN, Fraedrich SW 2011. Isolations from the redbay ambrosia beetle, Xyleborus glabratus, confirm that the laurel wilt pathogen, Raffaelea lauricola, originated in Asia. Mycologia 103: 1028-1036.

Hartill WFT 1987. Post-harvest rots of avocado in New Zealand. Australian Microbiologist 8: 154.

Hartill WFT 1991a. Postharvest diseases of avocado fruits in New Zealand. New Zealand Journal of Crop and Horticultural Science 19: 297-304.

Hartill WFT, Sale PR, Sawden D 1991b. Postharvest rots of avocados and their control. Proceedings of the 44th New Zealand Weed and Pest Control Conference: 232-236.

Hartill WFT, Everett KR 2002. Inoculum sources and infection pathways of pathogens causing stem-end rots of 'Hass' avocado (Persea americana). New Zealand Journal of Crop and Horticultural Science 30: 249-260.

Helson GAH 1966. Importation of nursery stock. In McLintock $\mathrm{AH}$ ed An Encyclopaedia of New Zealand. http://www.TeAra.govt.nz/ en/1966/quarantine-regulations-plants/page3 (accessed 14 April 2018).

Homsky S 1995. The avocado industry in Israelan overview. Alon Hanotea 49: 479-488.

HortPlus 2018. MetWatch Online. http:// hortplus.metwatch.co.nz/ (accessed 10 April 2018).
Hughes M, Smith JA, Mayfield AE, III, Minno MC, Shin K 2011. First report of laurel wilt disease caused by Raffaelea lauricola on pondspice in Florida. Plant Disease 95: 1588. Hughes MA, Shin K, Eickwort J, Smith JA 2012. First report of laurel wilt disease caused by Raffaelea lauricola on silk bay in Florida. Plant Disease 96: 910-911.

Jenkins AE 1934. Sphaceloma perseae the cause of avocado scab. Journal of Agricultural Research 49: 859-869.

Kasson MT, O’Donnell K, Rooney AP, Sink S, Ploetz RC, Ploetz JN, Konkol JL, Carrillo D, Freeman S, Mendel Z, Smith JA, Black AW, Hulcr J, Bateman C, Stefkova K, Campbell PR, Geering ADW, Dann EK, Eskalen A, Mohotti K, Short DPG, Aoki T, Fenstermacher KA, Davis DD, Geiser DM 2013. An inordinate fondness for Fusarium: Phylogenetic diversity of fusaria cultivated by ambrosia beetles in the genus Euwallacea on avocado and other plant hosts. Fungal Genetics and Biology 56: 147-157.

Kendra PE, Montgomery WS, Niogret J, Epsky ND 2013. An uncertain future for American Lauraceae: a lethal threat from redbay ambrosia beetle and laurel wilt disease (a review). American Journal of Plant Sciences 4: 727-738.

Koch FH, Smith WD 2008. Spatio-temporal analysis of Xyleborus glabratus (Coleoptera: Circulionidae: Scolytinae) invasion in Eastern U.S. forests. Environmental Entomology 37: 442-452.

Lynch SC, Twizeyimana M, Mayorquin JS, Wang DH, Na F, Kayim M, Kasson MT, Thu PQ, Bateman C, Rugmanjones P, Hulcr J, Stouthamer R, Eskalen A 2016. Identification, pathogenicity and abundance of Paracremonium pembeum sp nov and Graphium euwallaceae sp nov.-two newly discovered mycangial associates of the polyphagous shot hole borer (Euwallacea sp.) in California. Mycologia 108: 313-329.

MAF 2014. New Zealand Standard: 152.02: Importation and clearance of fresh fruit and vegetables into New Zealand. 7 January 2014. 
http://www.biosecurity.govt.nz/imports/ plants/standards/152-02.htm (accessed 3 February 2018).

Marroquin-Pimentel F 1998. Factores que favorecen la incidencia de rona Sphaceloma perseae Jenk. en el cultivo del aguacate Persea americana Mill. variedad 'Hass', en tres regiones agrocliaticas de Michoacan, Mexico. Thesis, Universidad Michoacana de San Nicolas de Hidalgo, Mexico. 56 p.

Marroquin-Pimentel F 1999. Factores que favorecen la incidencia de rona (Sphaceloma perseae Jenk.) en el cultivo del aguacate (Persea americana Mill.) 'Hass', en tres regiones agroclimaticas de Michoacan, Mexico. Revista Chapingo Serie Horticultura Mexico 5: 309-312.

Marroquin-Pimentel F 2000. La Rona del Aguacate. In: Teliz-Ortiz D ed. El Agucate y su Manejo Integrado. Editorial Mundi Prensa, Mexico. Pp. 146-148.

Mayfield AE, III, Smith JA, Hughes M, Dreaden TJ 2008. First report of laurel wilt disease caused by a Raffaelea sp. on avocado in Florida. Plant Disease 92: 976.

Mendel Z, Protasov A, Sharon M, Zveibil A, Yehuda SB, O’Donnell K, Rabaglia R, Wysoki M, Freeman S 2012. An Asian ambrosia beetle Euwallacea fornicatus and its novel symbiotic fungus Fusarium sp. pose a serious threat to the Israeli avocado industry. Phytoparasitica 40: 235-238.

Mendel Z, Protasov A, Maoz Y, Maymon M, Miller G, Elazar M, Freeman S 2017. The role of Euwallacea nr. fornicatus (Coleoptera: Scolytinae) in the wilt syndrome of avocado trees in Israel. Phytoparasitica 45: 341-359.

Minchin PEH, Thorp TG, Boldingh HL, Gould N, Cooney JM, Negm FB, Focht E, Arpaia $\mathrm{ML}, \mathrm{Hu} \mathrm{H}$, Brown $\mathrm{P}$ 2015. A possible mechanism for phloem transport of boron in 'Hass' avocado (Persea americana Mill.) trees. The Journal of Horticultural Science and Biotechnology, 87:1, 23-28.

MPI 2014. Import Health Standard: 155.02.06: Importation of Nursery Stock. 27 January 2014. http://www.biosecurity.govt.nz/ imports/plants/standards/155-02-06.htm (accessed 3 February 2018).

MPI 2018. Import Health Standard: 155.02.05: Seeds for sowing. 22 February 2018. http:// www.biosecurity.govt.nz/imports/plants/ standards/155-02-05.htm (accessed 10 April 2018).

$\mathrm{Na} F$, Carrillo JD, Mayorquin JS, NdingaMuniania C, Stajich JE, Stouthamer R, Huang YT, Lin YT, Chen CY, Eskalen A 2018. Two novel fungal symbionts Fusarium kuroshium sp nov and Graphium kuroshium sp nov of Kuroshio Shot Hole Borer (Euwallacea sp nr. fornicatus) cause Fusarium dieback on woody host species in California. Plant Disease 102(6): 1154-1164.

O'Donnell K, Sink S, Libeskind-Hadas R, Hulcr J, Kasson MT, Ploetz RC, Konkol JL, Ploetz JN, Carrillo D, Campbell A, Duncan RE, Liyanage PNH, Eskalen A, Na F, Geiser DM, Bateman C, Freeman S, Mendel Z, Sharon M, Aoki T, Cosse AA, Rooney AP 2015. Discordant phylogenies suggest repeated host shifts in the Fusarium-Euwallacea ambrosia beetle mutualism. Fungal Genetics and Biology 82: 277-290.

O’Donnell K, Libeskind-Hadas R, Hulcr J, Bateman C, Kasson MT, Ploetz RC, Konkol JL, Ploetz JN, Carrillo D, Campbell A, Duncan RE, Liyanage PNH, Eskalen A, Lynch SC, Geiser DM, Freeman S, Mendel Z, Sharon M, Aoki T, Cosse AA, Rooney AP 2016. Invasive Asian Fusarium - Euwallacea ambrosia beetle mutualists pose a serious threat to forests, urban landscapes and the avocado industry. Phytoparasitica 44(4): 435-442.

Paap T, de Beer ZW, Migliorini D, Nel WJ, Wingfield MJ 2018. The polyphagous shot hole borer (PSHB) and its fungal symbiont Fusarium euwallaceae: a new invasion in South Africa. Australasian Plant Pathology 47: 231-237.

Palmateer A 2006. Description of disease: avocado scab. In: Evans EA ed. Avocado Technical Assistance Curriculum. Institute of Food and Agricultural Sciences, University of Florida, Homestead. 77 p. 
Pegg K, Coates L, Korsten L, Harding R 2002. Foliar, Fruit and Soilborne Diseases. In: Whiley A, Schaffer B, Wolstenholme B eds. The Avocado. Botany, Production and Uses. CABI Publishing, Wallingford, UK; New York. Pp. 299-338.

Pena JE, Carrillo D, Duncan RE, Capinera JL, Brar G, McLean S, Arpaia ML, Focht E, Smith JA, Hughes M, Kendra PE 2012. Susceptibility of Persea spp. and other Lauraceae to attack by redbay ambrosia beetle, Xyleborus glabratus (Coleoptera: Curculionidae: Scolytinae). Florida Entomologist 95: 783-787.

Perez MRV, Ortiz DT, Almaraz RD, Martinez JOL, Angel DN 2017. Avocado sunblotch viroid: Pest risk and potential impact in Mexico. Crop Protection 99: 118-127.

Pernezny K, Marlatt R 2007. Diseases of avocado in Florida. Bulletin Florida Cooperative Extension Service PP21: 3.

Peterson R, Grice K 1992. Cercospora spot of avocado. Proceedings of the Australian Avocado Growers' Federation Conference.

Ploetz RC, Perez-Martinez JM, Smith JA, Hughes M, Dreaden TJ, Inch SA, Fu Y 2012. Responses of avocado to laurel wilt, caused by Raffaelea lauricola. Plant Pathology 61: 801-808.

Ploetz RC, Konkol J 2013. First report of gulf licaria, Licaria trianda, as a suscept of laurel wilt. Plant Disease 97: 1248-1249.

Pugh K, Thomson V 2009. Protecting our avocados. Biosecurity 93: 16-17.

Rabaglia RJ, Dole SA, Cognat AI 2006. Review of American Xyleborina (Coleoptera: Curculionidae : Scolytinae) occurring North of Mexico, with an illustrated key. Annals of the Entomological Society of America 99: 1034-1056.

Saucedo-Carabez JR, Teliz-Ortiz D, OchoaAscencio S, Ochoa-Martinez D, Vallejo-Perez MR, Beltran-Pena H 2014. Effect of Avocado sunblotch viroid (ASBVd) on avocado yield in Michoacan, Mexico. European Journal of Plant Pathology 138(4): 799-805.

Smith JA, Mount L, Mayfield AE, III, Bates CA, Lamborn WA, Fraedrich SW 2009. First report of laurel wilt disease caused by
Raffaelea lauricola on camphor in Florida and Georgia. Plant Disease 93: 198.

Stouthamer R, Rugman-Jones P, Thu PQ, Eskalen A, Thibault T, Hulcr J, Wang LJ, Jordal BH, Chen CY, Cooperband M, Lin CS 2017. Tracing the origin of a cryptic invader: phylogeography of the Euwallacea fornicatus (Coleoptera: Curculionidae: Scolytinae) species complex. Agricultural Forest Entomology 19: 366-375.

Vidales F 1996. La rona Sphaceloma persea del aguacate Persea americana en Michoacan. INIFAP, Campo Experimental Urapon, CIR Pacifico Centro. Michoocan, Mexico. Folleto Technico 4: 16.

Vidales F, Alcantar R, Anguiano C 1999. Modelos de prediccion de rona (Sphaceloma persea Jenkins), del aguacate (Persea americana Mill. cv. Hass) en Michoacan. Informe de investigacion en Aguacate. INIFAP, Campo Experimental Uruapan, CIR Pacifico Centro, Michoacan, Mexico. 14 p.

Wallace JM, Drake RJ 1962. A high rate of seed transmission of avocado sunblotch virus from symptomless trees and the origin of such trees. Phytopathology 52: 237.

White J 2001. The Avocado Industry in New Zealand. California Avocado Society Yearbook 85: 77-91.

Whiteside JO 1975. Biological characteristics of Elsinoe fawcettii pertaining to the epidemiology of sour orange scab. Phytopathology 65: 1170-1177.

Zentmeyer G 1965. Avocado culture and avocado diseases in Australia and the South Pacific. Californian Avocado Yearbook 49: 19-26. 